\title{
IN WHICH DIRECTION DO THE EFFORTS PROCEED? THE EUROPEAN UNION'S ATTEMPTS TO DEVELOP A COMMON IMMIGRATION AND ASYLUM POLICY
}

\section{N. Aslı ŞİRIN ÖNER*}

\section{Abstract}

In the period which began in the mid-1980s and continued until today, there has been an increase in the number of refugees, asylum-seekers and irregular migrants. The Central and Eastern Europeans, who had the opportunity to participate in the migration movements with the removal of the political barriers and the persons displaced as a result of bloody conflicts in the Balkans played an important role in the increase in the number of people migrating to the Western Europe.

The increase in the migratory pressures since the 1990s paved the way for the Western European states to tighten measures about immigration. This situation brought about the discussions on "fortress Europe" because the European Union tried to decrease the number of migrants entering the Union countries. However, the measures do not seem to be effective since more and more people enter the Union countries in an illegal way. This fact lies at the centre of the EU's wish to develop a common immigration and asylum policy. In this regard, the aim of this article is to elaborate on the attempts to develop a common immigration and asylum policy within the context of turning the EU territories into an "area of justice, freedom and security".

Keywords: Immigration, Asylum, "Fortress Europe", "Area of Freedom, Security and Justice"

\section{ÇABALAR HANGİ YÖNDE ILERLEYECEK? AVRUPA BİRLİĞİ'NİN ORTAK GÖÇ VE SIĞINMA POLITIKKASI OLUŞTURMA ÇABALARI}

\section{Özet}

1980'lerin ortalarında başlayıp günümüze dek devam eden dönemde mülteci, sığınmacı ve düzensiz göçmenlerin sayısında önemli ölçüde artış yaşanmıştır. Siyasi engellerin ortadan kalkmasıyla göç etme olanağını bulan Orta ve Doğu Avrupalılar

\footnotetext{
* Asst. Prof. Dr., Marmara University, Institute of European Union, Department of EU Politics and International Relations, e-mail: asli.sirin@marmara.edu.tr
} 
ile Balkanlar'daki kanlı çatışmalar sonucu yerlerinden edilen kişiler Batı Avrupa'ya göç edenlerin sayısındaki artışta önemli bir rol oynamıştı.

1990 'lardan bu yana göç basklsının artması, Batı Avrupa devletlerini konuyla ilgili düzenlemelerini sikılaştırmaya yöneltmiş; hatta bu durum "kale Avrupa" tartışmalarını beraberinde getirmişti, zira AB, Birlik ülkelerine giriş yapan göçmenlerin sayısını azaltmaya çalışıyordu. Ancak bu düzenlemelerin etkili olduklarını söylemek pek mümkün değil çünkü her geçen gün daha fazla sayıda insan Birlik ülkelerine yasadışı yollardan giriş yapıyor. AB'nin ortak bir göç ve siğınma politikası oluşturma isteğinin temelini de söz konusu gerçek oluşturuyor. Bu makalenin amacı da bahsi geçen gerçekten hareketle Birlik topraklarının "adalet, özgürlük ve güvenlik alanı" na dönüştürülmesi kapsamında ortak bir göç ve sığınma politikası oluşturma yolunda atılan adımları ele almaktır.

Anahtar Kelimeler: Göç, Slğınma, "Kale Avrupa”, "Özgürlük, Güvenlik ve Adalet Alanı"

\section{Introduction}

When we look at Europe in the post-World War II period, we see how migration has emerged as a social force and as well as a major challenge to the European states and societies. Of course we all know that Europe's experience with migration has not begun in the aftermath of the World War II. Europe was a stage for population movements in the 19 . century and early 20 . century, yet there are specific features which marked the post-1945 period. The first one of these features was related to the tragedy the Nazi Germany has created. The destructive fire caused by the Nazi regime and its plans for a new world order brought about the displacement and resettlement of millions. About 11 million people were displaced at the end of the World War II while several million more Europeans were affected by the redrawing of boundaries between Germany, Poland and Czechoslovakia and compulsory population transfers. The second feature was the increase in the volume of labour migration. After the World War II, the economic boom taking place as a part of the economic restructuring of Europe created a demand for workforce; and the Western European states tried to meet this demand by recruiting foreign labour. ${ }^{1}$

The recruitment of foreign labour continued until the mid-1970s when it came to a halt with the "oil crisis" of 1973 and the recession coming afterwards. The Western European states that ceased to recruit foreign labour expected the "guestworkers" to return to their countries yet even though they were offered material inducements, the guest-workers preferred to stay instead of going back. Faced with

\footnotetext{
${ }^{1}$ As a part of the recruitment of foreign labor, 10 million people migrated to Europe in the 1950-73 period (Stalker, 2002).
} 
such a situation, the Western European governments were flexible and they allowed the family reunion.

In the period that started in the mid-1980s and continued until today, there was an incredible increase in the number of refugees, asylum-seekers and irregular migrants. After the political changes of 1989-91 in the Eastern Bloc, the Central and Eastern Europeans, who had the opportunity to participate in the migration movements with the removal of the political barriers as well as the persons displaced as a result of bloody conflicts in the Balkans played an important role in the increase in the number of people migrating to the Western Europe.

As a result of the increase in the migratory pressures particularly since the $1990 \mathrm{~s}$ the Western European states were inclined to tighten measures about immigration. This situation brought about the discussions on "fortress Europe" because the European Union (EU), in one way or another tried to decrease the number of migrants entering the Union countries. However, the measures do not seem to be effective since more and more people try to enter the Union countries in an illegal way. This fact lies at the centre of the EU's wish to develop a common immigration and asylum policy.

In this article, deriving from the fact that controlling the migration directed to the EU territories has gained importance and international migration has started to be perceived as an issue of "security" in the post-Cold War period, I will elaborate on the attempts to develop a common immigration and asylum policy within the context of turning the EU territories into an "area of justice, freedom and security". What has the EU been doing in order to develop a common immigration and asylum policy? What is the current situation? Has the EU achieved anything so far? Those are the questions to which I am looking for an answer in this article. In the first part of the article, the focus is on the arrangements aimed at developing a common immigration and asylum policy in the pre-Maastricht period. The second part is about the arrangements in the Maastricht and Amsterdam Treaties which are regarded as the turning points in the process of developing the common policy. Lastly the recent developments in the process are elaborated.

\section{The Pre-Maastricht Arrangements Aimed at Developing a Common Immigration and Asylum Policy}

In the pre-Maastricht period, we come across with the EU's efforts to develop an immigration policy but the issue of asylum was not a part of these efforts. The founding treaty of the European Community, i.e. Treaty of Rome, included provisions on the free movement of workers, self-employed persons, and the 
nationals of a third country who provide services. ${ }^{2}$ These provisions show that the free movement was economically oriented because it would be valid for the workers who are indispensable for the operation of the internal market (Özgür and Özer, 2010). The main objective was to make maximum use of the intraCommunity labour potential of the member countries by providing the freedom of settlement and work. The freedom of movement, as stated in the Treaty of Rome, was achieved after a decade. Yet it is to be noted that the freedom of movement that became operative in 1968 was limited because it was a right granted only to the persons who were or who wanted to be economically active. The Regulation and Directive passed in the same year enabled the other members of the workers' families to make use of this right. ${ }^{3}$

In the 1970s, the member-states of the European Community (EC) started extending their work on developing a policy of immigration. In the previous period, emigration from the third countries was not considered as important, but when we analyse what was done in the aftermath of the 1973 crisis, we see that emigration from the third countries started to draw attention. For example, in 1974, the Council of Ministers approved the Commission's Social Action Plan which included arrangements intended for third country nationals and their families. The Social Action Plan proposed mandates in the areas of health and safety at work, minimum wages, working hours, employee participation, and the hiring of contract labour (Commission, 1974, quoted by Addison, 2009).

In the mid-1970s when the families of guest-workers were given the opportunity to migrate with the right to family reunion, the EC experienced its first enlargement and in the aftermath of the enlargement, in relation to the free movement of persons, considerations aimed at strengthening the Community borders started to emerge. The considerations in question continued at an increasing pace throughout the 1980s due to the fact that people fleeing conflicts were claiming asylum in the countries like the USA, Canada, the UK and Germany. Moreover, irregular migration had increased considerably. Because of the concerns the issue of asylum would remain on the EC's agenda and it would be considered in relation to irregular migration and particularly to the issues linked with illegal entry.

\footnotetext{
${ }^{2}$ The provisions on free movement are Article 48 about the free movement of workers, Article 52 about the free movement of self-employed persons, and Article 59 about the free movement of the nationals of a third country who provide services. For more see

Treaty of Rome, Retrieved: September 12, 2012, from http://ec.europa.eu/economy_finance/emu_history/documents/treaties/rometreaty2.pdf

${ }^{3}$ For more on the Regulation see Regulation (EEC) No 1612/68 of the Council of 15 October 1968 on freedom of movement for workers within the Community, Retrieved: September 12, 2012, from http://eurlex.europa.eu/LexUriServ/LexUriServ.do?uri=CONSLEG:1968R1612:20060430:EN:PDF
} 
In the 1980s, we witness important steps taken by the Community with regard to cooperation and integration. Some of the steps were directly related to the issues of immigration and asylum. Ad hoc groups were formed or some of the intergovernmental working groups incorporated the issues of immigration and asylum into their working areas. For example, the Trevi Group established within the framework of fight against terrorism extended its area of task in 1980. It would be concerned with the issues of "illegal" immigration and refugeehood, as well. The other intergovernmental ad hoc group was Migration Working Group established by the Council of Ministers in 1986. On the other hand, emphasis was put on the control of the external borders and the importance of developing an immigration policy. According to the then President of the Commission, Jacques Delors, if the internal borders were abolished, the member-states would have to cooperate in controlling the EC's external borders and this may be used in giving an institutional framework to the Community's immigration policy (Papadimitriou, 1996, quoted by Özgür and Özer, 2010). By the time Delors expressed his views about the abolition of internal borders, preparations had started for the Single European Act which was the EC's first reform. The Single European Act foresaw that the freedom of movement for goods, services, capital and persons would be achieved by the end of $1992 .^{4}$

While the preparations of the Single European Act continued, the Schengen Agreement, which is considered as the most important arrangement in the field of immigration and asylum before the signing of the Maastricht Treaty of 1992, was signed between the Benelux countries, France and Germany. In accordance with the provisions of the Agreement, the border controls would be gradually abolished among the signatories and visa policies would be harmonised. The border controls related to persons and goods would be completely abolished by January 1, 1990, but the reunification of Germany postponed this abolition and the Convention Implementing the Schengen Agreement was finally signed on June 19, 1990 (Toksöz, 2006). The Agreement started to be implemented in 1995. In the meantime, other states signed the Schengen Agreement. Italy signed in 1990, Spain and Portugal in 1991, Greece in 1992, Austria in 1995 when it joined the EU, Sweden and Finland and Denmark, with some reservations, signed in $1996 .{ }^{5}$

The Convention Implementing the Schengen Agreement foresaw the abolition of borders among the signatory states, the formation of a common external border and having common rules about the border controls. The rules in question included

\footnotetext{
${ }^{4}$ One of the important aspects of the common arrangement was about the third country nationals' travel to and residence in the EC. Yet none of the member-states had given up their right to control. They would still have the right to close their doors to the third country nationals (Toksöz, 2006).

${ }^{5}$ Even though they are not EU members, Monaco, Iceland and Norway signed the Schengen Agreement, as well.
} 
additional measures about applying a common visa regime at the external borders, cooperation in the fields of police, customs and justice, and fight against organised crime and terrorism. ${ }^{6}$ In accordance with the Agreement, Schengen Information System (SIS) would be established. SIS was the shared data-base formed to collect and share information on the border and police controls, the prevention of crime and the trial of the criminals, the granting visa and residence permits, and the implementation of laws aimed at compensating the abolition of controls at the internal borders. With the help of SIS, the national information systems (N-SIS) of the Schengen countries were connected to the central system (C-SIS) so information was passing from one system to the other. The authorised officials were also able to enter data to this technology system. The data entry was made possible with SIRENE (Supplementary Information Request at the National Entry) system.

While the governments of the EC member-states were involved in the steps taken in the field of immigration and asylum, the Council had taken its place in the process, as well. In the meeting held in Rhodes in 1988, there was a call to appoint an official who would be responsible for coordinating the EC's activities concerning the free movement of persons, and the appointed officials formed the "Coordinators' Group-Free movement of persons" which would be renamed as "K4 Coordinating Committee" after the EC became the EU. In 1989, this Group prepared the Palma Document that emphasised the free movement of persons within the internal borders of the EC on the one hand and the strengthening of controls at the external borders. ${ }^{7}$ In 1989 when the Palma Document was adopted there was another development. The Community Charter of the Fundamental Social Rights of Workers, known as the Social Charter was adopted on 9 December. According to the Charter, the member-states would be obliged to make the arrangements so that the workers of the third countries residing in their territories would have the same working and life conditions with the native workers.

In the 1990s, the collapse of the Eastern Bloc with the 1989 Revolutions resulted in the increase in the EC's security concerns because the collapse of the Bloc brought with it worries of migrant influx from the East to the West. So we have to evaluate the Dublin Convention in this context. The preparations for the Convention started at an intergovernmental level and it was signed on 15 June 1990. The Dublin Convention was specifically on asylum. It obliged the country through which asylum seekers first enter the EU to handle applications for asylum

\footnotetext{
${ }^{6}$ For more see İktisadi Kalkınma Vakfı, AB Kavramları Sözlügü, Retrieved: September 13, 2012, from http://www.ikv.org.tr/sozluk.asp?bas_harf=S\&anahtar=\&sayfa=\&id=1257

${ }^{7}$ For more see Palma Documents, Reference: DOC/89/1, 27.06.1989, Retrieved: September 13, 2012, from

http://europa.eu/rapid/pressReleasesAction.do?reference=DOC/89/1\&format=HTML\&aged=1\&languag $\mathrm{e}=\mathrm{EN} \&$ guiLanguage $=\mathrm{en}$
} 
on behalf of all other member-states, unless there are good reasons why the case should be handled by another state. The aim was to prevent refugees from making multiple asylum applications or targeting more friendly countries.

The Ministers responsible for immigration of the member-states discussed the basic elements of the Dublin Convention in a meeting held on 30 November - 1 December 1992. In this meeting, in order to prevent the "bogus refugees", the Ministers decided to declare the asylum applications, which do not meet the criteria stated in the UN Convention relating to the Status of Refugees (1951) and the New York Protocol (1967), "openly groundless and to send the persons, whose applications have been rejected, to the "safe third countries" (Lavenex, 1999). The safe third countries in question were the Central and Eastern European countries (CEECs) that have become EU members with the enlargements in 2004 and 2007. The Dublin Convention went into force in $12 \mathrm{EU}$ member-states in September 1997, in Austria and Sweden in October 1997 and finally in Finland in January 1998. The Convention, which set the rules for sharing responsibility about the examination of the asylum applications among the member-states, was an intergovernmental arrangement and was not binding on the member-states with regard to the harmonization of their domestic laws.

In order to make the arrangements which are binding on all member-states, the founding Treaties had to be amended and each member-state had to give consent to the amendments. This was an obstacle and it was tried to be surpassed with the pillar system that was introduced by the Maastricht Treaty. The Treaty on European Union (TEU), commonly known as the Maastricht Treaty, which was signed in 1992, turned the EC to a political union based on three pillars, namely "European Communities", "Common Foreign and Security Policy" and "Cooperation in the field of Justice and Home Affairs". The Maastricht Treaty and the Treaty of Amsterdam that is considered as the first comprehensive reform of the Maastricht Treaty are regarded as the turning points in developing a common immigration and asylum policy. I will elaborate the reasons of this situation in the next section.

\section{The Turning Points in Developing a Common Immigration and Asylum Policy: Maastricht and Amsterdam Treaties}

\subsection{Maastricht Treaty}

Why was the Maastricht Treaty, which went into force in November 1993, considered as the turning point in developing a common immigration and asylum policy? First of all, this treaty integrated the migration policies that were tried to be formed during the Community period into the single institutional structure of the EU. The issues covering the fields of immigration and asylum were set out in Article K of Title VI named "Provisions on Cooperation in the Fields of Justice and Home Affairs". According to the Article K, asylum policy, rules on external border 
controls, immigration policy, and rules for third-country nationals within the EU, ${ }^{8}$ combating drug addiction and international fraud, judicial cooperation in civil and criminal matters, customs cooperation, and police cooperation to combat terrorism, drug trafficking and other serious international crime were listed as the "matters of common interest". As Lahav (2004) emphasises, even though the "matters of common interest" were to be dealt with on an intergovernmental basis, the goals and implementation strategies were left to national and administrative interpretation. The member-states had extensive discretion and since "... migration matters were not necessarily the domain of the Commission, nor were decisions automatically subject to judicial review by the Court of Justice" (ibid.).

Although the subjects concerning the fields of immigration and asylum were in the third pillar, only one subject in the field of asylum was integrated into the communitarised First Pillar by Art. 100(c) TEC which says "The Council, acting unanimously on a proposal from the Commission and after consulting the European Parliament, would determine the third countries whose nationals must be in possession of a visa when crossing the external borders of the Member States. ${ }^{9}$ The arrangement of this issue in the First Pillar shows that the member-states have reached an agreement on the issue yet the fact that consultation procedure would be applied instead of co-decision procedure was remarkable. In accordance with the consultation procedure, the countries whose nationals were supposed to get visa would be determined by the unanimous decision of the member-states due to the fact that the Council of Ministers was obliged only to consult the European Parliament (EP) meaning that it did not have to act in accordance with the opinion of the EP. This arrangement concerning the issue of visa showed us how important and sensitive it was for the member-states.

Another reason of considering the Maastricht Treaty as the turning point in developing a common immigration and asylum policy is that it laid the foundations of the motivating factors which showed the necessity to have a common asylum system and the mechanisms that would be formed to achieve this objective (Özgür and Özer, 2010). So, on the one hand, a European common market in which the free movement of persons, goods, capital and services was assured in the EU and, on the

\footnotetext{
${ }^{8}$ The immigration policy and policy regarding nationals of third countries include (a) conditions of entry and movement by nationals of third countries on the territory of Member States; (b) conditions of residence by nationals of third countries on the territory of Member States, including family reunion and access to employment; and (c) combatting unauthorized immigration, residence and work by nationals of third countries on the territory of Member States. Treaty on European Union, Official Journal C 191, 29 July 1992, Retrieved: September 15, 2012, from http://eur-lex.europa.eu/en/treaties/dat/11992M/htm/11992M.html

${ }^{9}$ Treaty on European Union, Official Journal C 191, 29 July 1992, Retrieved: September 15, 2012, from http://eur-lex.europa.eu/en/treaties/dat/11992M/htm/11992M.html
} 
other, the European Union citizenship was formed with the Article 17 of the First Pillar. According to the Article 17, the nationals of the member-states would be EU citizens. Hence the nationals of a member-state were granted the right to free movement and settlement in the territory of another member-state.

The EU citizenship brought with it many criticisms. The most important one was that the EU citizenship did not include the persons who were residing on the EU territories but were not nationals of any member-state. As Maas (2008) notes, the existence and growth of settled populations excluded from the freedoms of movement and citizenship decreases the ideal of the Union as a shared space of these freedoms. If we think about the fact that the number of third country nationals legally resident in the Union has exceeded 19 million and accounts for approximately $4 \%$ of the EU population, then this exclusion paves the way for questioning the legitimacy of the EU citizenship (ibid.). While these people were not represented because they were not citizens, how could we talk about a common European identity?

In the structure formed with the Maastricht Treaty consensus has been reached over certain migration-related issues. They were mainly the Union citizenship, the free movement and settlement of the EU citizens and the specification of the countries that would require visa from the persons coming from the external borders of the EU. But there was no measure adopted in the field of asylum. The amendments that included this field would take place in the period following the signature of the Treaty of Amsterdam.

\subsection{Treaty of Amsterdam}

The second turning point in developing a common immigration and asylum policy is the Treaty of Amsterdam which has given a shape to the Third Pillar of the Maastricht Treaty by forming an "area of freedom, security and justice".

The issues of free movement, checks at the external borders, asylum, immigration and the protection of the rights of non-EU nationals, and judicial cooperation in civil matters were transferred to the First Pillar. ${ }^{10}$ But we also have to note that even though the subjects of immigration and asylum were transferred to the First Pillar, the intergovernmental mechanism would still be the decisionmaking for the next five years (Özgür and Özer, 2010). Only after five years, the matters will be subject to the co-decision procedure as a result of the unanimous decision of the member-states. In the areas where the co-decision procedure is applied, the member-states were not the final and single authority. Meanwhile, the

\footnotetext{
10 Treaty of Amsterdam Amending the Treaty on European Union, the Treaties Establishing the European Communities and Certain Related Acts, Retrieved: September 17, 2012, from http://www.ab.gov.tr/files/ardb/evt/1_avrupa_birligi/1_3_antlasmalar/1_3_2_tadil_antlasmalari/1997_a mterdan_treaty_eng.pdf
} 
issues such as prevention of crime, combat against terrorism, drug trafficking and judicial cooperation in criminal matters remained in the Third Pillar.

The transfer from the Third to the First Pillar was an important amendment of the Treaty of Amsterdam. The Council of Ministers was obliged to adopt measures concerning the abolition of checks of both the EU citizens and the third country nationals at the internal borders, the passing from the external borders, the third country nationals who would benefit from the freedom of travel on the territories of the member-states with the condition that travel would not exceed three months.

The other important amendment was concerning the Schengen Agreement. The Schengen acquis was integrated into the EU framework through a protocol annexed to the TEU and Treaty. ${ }^{11}$ The Council of Ministers was responsible for unanimously taking the decisions which would enable the implementation of the Schengen acquis. The Schengen area was extended with each enlargement of the EU. The CEECs have gradually participated in the Schengen system. ${ }^{12}$ The integration of the Schengen Agreement into the acquis is of considerable importance in the sense that it shows the consensus of the member-states about the communitarising the control of the external borders.

Another reason of considering the Treaty of Amsterdam the other turning point in developing a common immigration and asylum policy is the fact that the issue of immigration and asylum is set up by a specific Article (Art. 63). The Council of Ministers would adopt measures on asylum, refugees and displaced persons, immigration policy, and measures defining the rights and conditions under which nationals of third countries who are legally resident in a member-state may reside in other member-states.

After elaborating the two Treaties important in developing an immigration and asylum policy in the $1990 \mathrm{~s}$, it is time to have a look at what has been done in the 2000s. We may say that the process that would help us understand the point reached so far has begun with the Tampere EU Council of 1999.

\footnotetext{
${ }^{11}$ This measure was adopted by a Protocol due of the reservations of some of the member-states. For example, the UK and Ireland have declared that they would not participate in the implementations which included the Schengen arrangements, yet they participated in certain fields such as the provisions on police and judicial cooperation in criminal matters, fight against drugs and SIS. For more see (Özgür and Özer, 2010).

${ }^{12}$ Albeit not an EU member, a couple of countries have participated in the Schengen system. Norway, Iceland, Liechtenstein and Switzerland are among those countries.
} 


\section{A New Era in Developing a Common Immigration and Asylum Policy: Developments in the 21th Century}

\subsection{The Tampere European Council and Phase I (2000-2005)}

In the post-Maastricht and Amsterdam Treaties period, the first notable development with regard to forming a common immigration and asylum policy is the Tampere European Council of 1999 because it lays the sources of secondary law such as regulation, directive, decision, recommendation and opinion which are binding like the Founding Treaties. As Özgür and Özer (2010) note, this European Council is important in the sense that it started the process of gradually forming common policies on immigration and asylum. It was expressed in the European Council that the common EU policy on immigration, visa and asylum should include certain elements. These are the partnership with the immigrant and refugees' countries of origin, a common European asylum system, the fair treatment of TCNs, and the management of migration flows including severe sanctions on those who engage in trafficking in human beings and economic exploitation of migrants. ${ }^{13}$

In the Presidency Conclusions of the Tampere European Council, certain issues have been addressed under the Title "A Common EU Asylum and Migration Policy". These issues include political, human rights and development issues in countries and regions of origin and transit. Moreover, it has been "... .agreed to work towards establishing a Common European Asylum System, based on the full and inclusive application of the Geneva Convention, thus ensuring that nobody is sent back to persecution" (Tampere Presidency Conclusions, 15-16 October, 1999). With the help of such a system, a common asylum procedure would be formed. It would be valid for everybody coming to a member-state with an asylum claim.

In accordance with the Presidency Conclusions, this common policy would be developed in two phases. In the first phase, the minimum standards would be formed, and in the second one the laws in the key areas would be harmonised (IOM, 2003: 261). Through this means, the member-states would be able to change the responsibilities deriving from the policies implemented individually with the condition that they would take the Community policy into account. Moreover, it was made possible for the member-states with different asylum systems to form a Common European Asylum System by harmonising their policies.

The measures adopted for forming a Common European Asylum System are in the form of sources of secondary law such as regulation, directive and etc. These measures can be grouped in two categories: a) measures concerning the external

\footnotetext{
${ }^{13}$ Tampere Summit Conclusions, 15-16 October 1999, Retrieved: September 18, 2012, from http://www.statewatch.org/news/2008/aug/tamp.html
} 
borders of the Union which are aimed at preventing illegal migration, and b) measures concerning the persons who are legally residing in the Union territories.

If we examine the measures concerning the external borders of the Union, we see that the establishment of EURODAC and measures about immigration and immigrants are prevalent. EURODAC is supplementary to the measures concerning the control of the external borders. It is a system used by the member-states in identifying the applicants of asylum and the persons caught while trying illegally to cross the border. ${ }^{14}$ Among the measures concerning immigration and immigrants European Migration Network which was put into practice in 2002 and Council Regulation (EC) of 2002 laying down a uniform format for residence permits for third-country nationals that was aimed at preventing illegal immigration and residence are noteworthy. In addition, there are measures specifically concerning asylum-seekers. The Dublin II Regulation and the Council Directive of 2003 on the standards for the reception of asylum seekers are the most important of these measures. The Dublin II Regulation is important in the sense that it “... replaces the provisions of the 1990 Dublin Convention with Community legislation, and the objective is to identify as quickly as possible the Member State responsible for examining an asylum application, to establish reasonable time limits for each of the phases of determining the Member State responsible, and to prevent abuse of asylum procedures in the form of multiple applications". ${ }^{15}$ The Council Directive about the standards for the reception of asylum seekers aims to determine the minimum standards for the reception of asylum-seekers. According to the provisions of the Council Directive, ${ }^{16}$ "member-states shall inform asylum seekers, within a reasonable time not exceeding fifteen days after they have lodged their application for asylum with the competent authority, of at least any established benefits and of the obligations with which they must comply relating to reception conditions", and they "shall adopt the necessary measures to provide asylum seekers with the document issued in his or her own name certifying his or her status as an asylum seeker or testifying that he or she is allowed to stay in the territory of the Member State while his or her application is pending or being examined". ${ }^{17}$ Moreover, the applicant should not be prevented from access to labour market and vocational training after six months pass over his/her application.

\footnotetext{
${ }^{14}$ EURODAC obliges not only the EU member-states but also Iceland, Norway and Switzerland. Moreover, I have to note that even though Denmark, Ireland and the UK are out for the Schengen system, they are included both in the Dublin Convention and EURODAC.

${ }^{15}$ Dublin II Regulation, Retrieved: September 18, 2012, from

http://europa.eu/legislation_summaries/justice_freedom_security/free_movement_of_persons_asylum_i mmigration/133153_en.htm

${ }^{16}$ The Council Directive is binding on all member-states except Denmark and Ireland.

${ }^{17}$ Council Directive 2003/9/EC of 27 January 2003 laying down minimum standards for the reception of asylum seekers, Retrieved: September 19, 2012, from

http://eur-lex.europa.eu/LexUriServ/LexUriServ.do?uri=OJ:L:2003:031:0018:0025:EN:PDF
} 
In addition to the Regulation and Directive mentioned above, the establishment of Frontex in October 2004 is one of the important developments of the postTampere Council period. ${ }^{18}$ Frontex is the European agency for the management of operational cooperation at the external borders of the member-states of the EU. Its main objective is to promote, coordinate and develop an integrated European border management in line with the EU fundamental rights charter applying the concept of Integrated Border Management. ${ }^{19}$ Although the member-states are responsible for the control and surveillance of the external borders of the EU, Frontex is an important agency in the sense that it aims to facilitate the implementation of both the existing and the would-be Community measures adopted.

The intra-EU measures are, as mentioned above, concerning the persons who are legally residing in the Union territories. We may list the measures prepared during the 2003-5 period as follows: the Council Directive of 2003 to determine the conditions for the exercise of the right to family reunification by third country nationals residing lawfully in the territory of the Member States, the Council Directive of 2003 concerning the status of third-country nationals who are longterm residents, the Directive of the European Parliament and the Council of 2004 on the right of citizens of the Union and their family members to move and reside freely within the territory of the Member States, Council Directive of 2004 on the conditions of admission of third-country nationals for the purposes of studies, pupil exchange, unremunerated training or voluntary service, the Council Directive of 2004 on minimum standards for the qualification and status of third-country nationals and stateless persons as refugees, and the Council Directive of 2005 minimum standards on procedures in Member States for granting and withdrawing refugee status.

The EU, as Özgür and Özer (2010) note, has aimed to harmonise the legal framework of the member-states in the field of asylum by setting common minimum standards. We may say that the standards in question are essentially the protection of the EU's external borders and the formation of a legal and institutional structure binding on the member-states. In the 2000-2005 period, economy and security were prominent concerns of the EU. The obstacles in front of developing a common European immigration and asylum policy have mainly been about the financial issues and the transfer of authority concerning these issues. In order to eliminate the obstacles in question the Hague Programme was adopted in the Brussels Council of November 2004. The Hague Programme included the measures that would be implemented in the 2005-10 period.

\footnotetext{
${ }^{18}$ It became operational in 2005.

19 Frontex, Mission and Tasks, Retrieved: September 19, 2012, from http://frontex.europa.eu/about/mission-and-tasks
} 


\subsection{The Hague Programme and Phase II (2005-2010)}

The Hague programme draws attention to the necessity of developing a holistic approach that includes all stages of migration and aims at strengthening the area of freedom, security and justice within the EU. ${ }^{20}$ After the terrorist attacks in the USA and Spain in 2001 and 2004 respectively, the security of both the EU and the member-states have gained urgency and this has been reflected in the Hague Programme. When we examine the measures set forth in the Programme, we see that the protection of the EU's external borders is still quite important.

In accordance with the Programme, the second phase of developing a common immigration and asylum policy began in May 2004. In that regard, the goal was to form a common asylum procedure and a single status concerning the people who are granted secondary protection and refugee statuses. The required measures would be set up by the end of 2010. Moreover, a new European Refugee Fund was established for the 2005-10 period. The points emphasised in the Programme include the role of migration in the development of European economy based on knowledge, the necessity to have cooperation among the national policies concerning the integration of legal migrants with residence permits, the importance of giving support to the efforts of both the origin and transit countries in the protection of refugees, and the importance and necessity to deal with migration in a holistic way based on dialogue and cooperation with the countries and regions of origin. Moreover, the Council drew attention to the interoperability of Schengen and Visa Information Systems and EURODAC and proposed the establishment of common visa offices in the long-term.

Among the measures adopted for the Phase II which began with the Hague Programme, the ones related to forming funds, specifying the deficiencies in the implementation and preparing a common European resettlement programme come to fore. ${ }^{21}$ The measure concerning the formation of funds was the decision to establish the European Integration Fund in 2007 and the Return Fund in 2008. ${ }^{22}$ In

\footnotetext{
${ }^{20}$ The Hague Programme - Strengthening Freedom, Security and Justice in the European Union, Retrieved: September 20, 2012, from

http://eur-lex.europa.eu/LexUriServ/LexUriServ.do?uri=OJ:C:2005:053:0001:0014:EN:PDF

${ }^{21}$ The other measures are related to the signing of new readmission agreements, the establishment of European Migration Network, and the preparation of the Directive on return of the unregistered migrants. Moreover, in 2009, the Council adopted a Directive on the conditions of entry and residence of third-country nationals for the purposes of highly qualified employment. "This directive concerns conditions of entry for highly qualified non-EU nationals. It creates a 'European Blue Card' and sets out the conditions and rights of residence in the issuing as well as in other Member States." [Entry and residence of highly qualified workers (EU Blue Card), Retrieved: September 20, 2012, from http://europa.eu/legislation_summaries/justice_freedom_security/free_movement_of_persons_asylum_i mmigration/114573_en.htm]

${ }^{22}$ The European Integration Fund would cover the 2007-2013 period, and the Return Fund would cover the 2008-2013 period.
} 
addition, deficiencies in the implementation field were specified and a Policy Plan on Asylum to dispel the deficiencies was adopted in 2008. The Plan was a road map for completing the II. Phase of Common European Asylum System. It “...proposes to supplement the existing instruments of the Common European Asylum System. Such ambitious legislative action must, however, be backed up by enhanced practical cooperation on asylum. The significant differences in the 27 Member States' decision-making procedures to deal with applications for international protection do not arise simply from the need for greater legislative harmonisation. They also arise from other, non-legislative factors, including the differing traditions and practices of the Member States and, in particular, from differences in the information on the country of origin of applicants for international protection. This is why strengthening practical cooperation on asylum between the Member States is very important for achieving convergence between them in the processing of applications for international protection". ${ }^{23}$ Moreover, the Commission prepared a proposal including ten principles on which a Common European Immigration Policy would be articulated and the actions required to carry out the principles in question. These principles may be grouped under the following headings: a) prosperity emphasising a contribution of legal immigration to the socio-economic development of the EU, b) solidarity drawing attention to coordination between Member States and cooperation with third countries, and c) security stressing an effective fight against illegal immigration.

In addition to the funds and measures concerning the dispelling of deficiencies in the implementation field, the preparation of a Joint EU resettlement programme is noteworthy, as well. The issue of resettlement requires addressing the issue of asylum together with the external policy actions of the EU and incorporating it into the Regional Protection Programme that would be formed in the future. Thus the EU considers the issue of resettlement as an inseparable element of the Common European Asylum System which is aimed to be established. That is why, in 2009, the Commission proposed preparing a Joint EU resettlement programme which is about resettling the refugees coming from outside the EU to one of the memberstates (Özgür and Özer, 2010). The aim is to develop international protection of refugees and achieve solidarity with the third countries. Moreover, the Commission would continue giving support to the resettlement projects by making use of the European Refugee Fund.

The legal and institutional framework set by the EU Founding Treaties plays an important role in concretising these proposals and measures in question. In that regard, we have to examine how the Treaty of Lisbon, which may be considered as

\footnotetext{
${ }^{23}$ Proposal for a Regulation of the European Parliament and of the Council establishing a European Asylum Support Office, Retrieved: September 20, 2012, from http://eur-lex.europa.eu/LexUriServ/LexUriServ.do?uri=CELEX:52009PC0066:EN:NOT
} 
the last revision of the Founding Treaties, addresses the issue of immigration and asylum. In addition, we have to note that the Stockholm Programme has replaced the Hague Programme after the year 2010. The Stockholm Programme sets out the EU's priorities for the area of justice, freedom and security for the period 2010-14. The main objective is " ... to provide a secure Europe where the fundamental rights and freedoms of citizens are respected". ${ }^{24}$ In this Programme, as in the previous ones, one may sense security concerns of the Union, yet we may say that there is more emphasis on protecting the fundamental rights.

\subsection{The Treaty of Lisbon}

The Treaty of Lisbon, which entered into force in December 2009, amends the EU's two core treaties, namely the Treaty on European Union (TEU) and the Treaty Establishing the European Community (TEC). The TEC has been renamed the Treaty on the Functioning of the EU (TFEU). ${ }^{25}$ So the three-pillar structure of the Maastricht Treaty has been replaced with a two-pillar structure. The TEU includes provisions on the main conditions of the structuring of the EU, objectives and the organisation of the EU while the TFEU specifies the measures concerning the functioning of the EU and the EU institutions' areas of jurisdiction.

The measures in the field of immigration and asylum are in the Title V (Area of Freedom, Security and Justice) of the TFEU. In this area, competence is shared between the EU institutions and the member-states. Before the Treaty of Lisbon, the issues related to the area of freedom, security and justice, which have been addressed in the 3 . Pillar, are under the Community Pillar. In particular, the subjects of immigration and asylum are addressed in the following chapters of the Title V: Policies on border checks, asylum and immigration (Chapter 2), Judicial cooperation in civil matters (Chapter 3), Judicial cooperation in criminal matters (Chapter 4), Police cooperation (Chapter 5). The parts crucial for the structuring in the field of asylum are in the chapters on General Provisions and Policies on border checks, asylum and immigration. In Article 67 of General Provisions it is stated as follows:

2. The Union shall ensure the absence of internal border controls for persons and shall frame a common policy on asylum, immigration and external border control, based on solidarity between Member States, which is fair towards third-country nationals.

\footnotetext{
${ }^{24}$ The Stockholm Programme, Retrieved: September 21, 2012, from http://europa.eu/legislation_summaries/human_rights/fundamental_rights_within_european_union/j1003 4 en.htm

${ }^{25}$ Treaty of Lisbon amending the Treaty on European Union and the Treaty establishing the European Community, signed at Lisbon, 13 December 2007, Official Journal of the European Union 306, Vol. 50, 17.12.2007, Retrieved: September 21, 2012, from http://eur-lex.europa.eu/JOHtml.do?uri=OJ:C:2007:306:SOM:EN:HTML
} 
3. The Union shall endeavour to ensure a high level of security through measures to prevent and combat crime, racism and xenophobia, and through measures for coordination and cooperation between police and judicial authorities and other competent authorities, as well as through the mutual recognition of judgments in criminal matters and, if necessary, through the approximation of criminal laws. ${ }^{26}$

The Chapter 2 includes measures concerning checks on persons and efficient monitoring of the crossing of external borders; and the gradual introduction of an integrated management system for external borders.

The Treaty of Lisbon is important in the sense that it brings novelties. For example, the subjects related to internal security and integrated management of the external borders are addressed in the Treaty for the first time. Moreover, apart from the refugee and secondary protection statuses, a temporary protection status has been created with the Treaty. Therefore, protection would be provided to the asylum-seekers in three different categories. In addition, as stated in the TEU, the Treaty of Lisbon recognises the rights, freedoms and principles set out in the Charter of Fundamental Rights and gives its provisions a binding legal force. It is concerned with civil, political, economic and social rights. Since the right to asylum is recognised in the Charter of Fundamental Rights, it is guaranteed with the Treaty of Lisbon.

The subjects of immigration and asylum are mostly incorporated into the community mechanism. As a result, decisions are taken jointly by the Council of Ministers and the European Parliament. On the other hand, we will see to what extent the European Court of Justice and the Charter of Fundamental Rights will be influential in the field of immigration and asylum. The rearrangement of the Directives concerning asylum is important in the sense that it shows that the EU, whose acquis is criticised for violating the rights of immigrants and asylum-seekers, does not ignore those criticisms. The concept of "Fortress Europe" has not disappeared yet but the EU is trying to provide the immigrants with legal status with the rights close to the rights of the EU citizens and protect the fundamental rights and freedoms within the Union. We should not disregard this fact.

\section{Concluding Remarks}

We have been witnessing that the EU, since its establishment, tried to achieve the freedom of movement of persons, goods, services and capital because these four freedoms are the keystones of the single market. In the 1980s and 1990s when the migration influx towards the EU territories was expected, legal and institutional measures were taken in the field of immigration as a result of the increasing

\footnotetext{
${ }^{26}$ Treaty of Lisbon, Title V, Chapter 1 - General Provisions, Retrieved: September 22, 2012, from http://www.statewatch.org/news/2009/nov/lisbon-treaty-jha.pdf
} 
perceptions of external threat to the Union's area of freedom. The subjects of immigration and asylum were first specified as the "matters of common interest" in the Maastricht Treaty and then communitarised with the Treaty of Amsterdam. In that regard, the Treaties of Maastricht and Amsterdam are the turning points of the process of developing a common immigration and asylum policy. After the Treaty of Amsterdam, the legal and institutional measures required for the policy were taken.

The Treaty of Lisbon is important in terms of legal and institutional structuring of the Union. When we look at the field of immigration and asylum, we see that the EU is trying to communitarise this field in institutional terms. We have evaluated the co-decision procedure becoming a general rule and the strengthening of both the European Parliament and the Court of Justice in this context. As a result, the measures binding on all member-states are taken more easily. But still we are faced with an important problem: Will the legal measures be implemented by the member-states in the same way? Since the member-states are not willing to transfer the measures that are binding on all member-states to their domestic laws, there are differences in the implementation field and these differences constitute an obstacle to developing a common immigration and asylum policy. In addition, there is no efficient control mechanism concerning the implementation of the Council Directives. Thus we cannot talk of any sanction on the member-states which do not implement the Directives.

I want to conclude by saying that it is a bit early to comment on whether the efforts of the EU to develop a common immigration and asylum policy will bear results or not because we have to wait for after 2017 when the decision-making mechanism formed with the Treaty of Lisbon will have full operability because we have to evaluate the situation after that. The process, which started with the Stockholm Programme and the Treaty of Lisbon, is a process in which we will observe to what extent the implementations of the member-states in the field of immigration and asylum becomes common and Europeanised. Overall the steps that the EU has taken so far are promising but still the implementations of the memberstates will determine whether the efforts result in the desired way or remain futile. 


\section{References:}

Addison, John T. (2009), "In the Beginning, There Was Social Policy: Developments in Social Policy in the European Union From 1972 Through 2008”, The Rimini Centre for Economic Analysis, PR 01-09

Council Directive 2003/9/EC of 27 January 2003 laying down minimum standards for the reception of asylum seekers, Retrieved: September 19, 2012, from http://eurlex.europa.eu/LexUriServ/LexUriServ.do?uri=OJ:L:2003:031:0018:0025:EN:PDF

Dublin II Regulation, Retrieved: September 18, 2012, from http://europa.eu/legislation summaries/justice_freedom_security/free_movement_of_persons_asylum_immigration/1 33153 en.htm

Entry and residence of highly qualified workers (EU Blue Card) Retrieved: September 20, 2012,from http://europa.eu/legislation_summaries/justice_freedom_security/free_move ment_of_persons_asylum_immigration/114573_en.htm

Frontex, Mission and Tasks, Retrieved: September 19, 2012, from http://frontex.europa.eu/about/mission-and-tasks

İktisadi Kalkınma Vakfı, AB Kavramları Sözlüğü, Retrieved: September 13, 2012, from http://www.ikv.org.tr/sozluk.asp?bas_harf=S\&anahtar=\&sayfa=\&id=1257

International Organisation for Migration (2003), World Migration 2003 Managing Migration Challenges and Responses for People on the Move, Vol. 2, Geneva: IOM World Migration Report Series, Retrieved: September 18, 2012, from http://publications.iom.int/bookstore/free/WMR_2003.pdf

Lahav, Gallya (2004), Immigration and Politics in the New Europe: Reinventing Borders, the UK: Cambridge University Press.

Lavenex, Sandra (1999), Safe Third Countries: Extending the EU Asylum and Immigration Policies to central and Eastern Europe, Hungary and the USA: Central European University Press.

Maas, Willem (2008), "Migrants, States, and EU Citizenship's Unfulfilled Promise", Citizenship Studies (12) 6: 583-596.

Özgür, Nurcan and Yeşim Özer (2010), Türkiye’de Sığınma Sisteminin Avrupalılaştırılması, İstanbul: Derin Yayınları

Palma Documents, Reference: DOC/89/1, 27.06.1989. Retrieved: September 13, 2012, from http://europa.eu/rapid/pressReleasesAction.do?reference=DOC/89/1\&format=HTML\&ag ed $=1 \&$ language $=$ EN\&guiLanguage $=$ en

Proposal for a Regulation of the European Parliament and of the Council establishing a European Asylum Support Office, Retrieved: September 20, 2012, from http://eurlex.europa.eu/LexUriServ/LexUriServ.do?uri=CELEX:52009PC0066:EN:NOT 
Regulation (EEC) No 1612/68 of the Council of 15 October 1968 on freedom of movement for workers within the Community, Retrieved: September 12, 2012, from http://eurlex.europa.eu/LexUriServ/LexUriServ.do?uri=CONSLEG:1968R1612:2006043 $0: \mathrm{EN}: \mathrm{PDF}$

Stalker, Peter (2002), "Migration Trends and Migration Policy in Europe", International Migration, Vol 40 (5): 151-179

Tampere Summit Conclusions, 15-16 October 1999, Retrieved: September 18, 2012, from http://www.statewatch.org/news/2008/aug/tamp.html

T.C. Başbakanlık Dış Ticaret Müsteşarlı̆̆ı (2007), Avrupa Birliği ve Türkiye, Ankara, 6. Bask1.

The Hague Programme - Strengthening Freedom, Security and Justice in the European Union, Retrieved: September 20, 2012, from http://www.europol.europa.eu/jit/hague_ programme_en.pdf

Toksöz, Gülay (2006), Uluslararası Emek Göçü, İstanbul: İstanbul Bilgi Üniversitesi Yayınları

Treaty of Amsterdam Amending the Treaty on European Union, the Treaties Establishing the European Communities and Certain Related Acts, Retrieved: September 17, 2012, from http://www.europarl.europa.eu/topics/treaty/pdf/amst-en.pdf

Treaty on European Union, Official Journal C 191, 29 July 1992 Retrieved: September 15, 2012, from http://eur-lex.europa.eu/en/treaties/dat/11992M/htm/11992M.html

Treaty of Lisbon amending the Treaty on European Union and the Treaty establishing the European Community, signed at Lisbon, 13 December 2007, Official Journal of the European Union 306, Vol. 50, 17.12.2007, Retrieved: September 22, 2012, from http://eur-lex.europa.eu/JOHtml.do?uri=OJ:C:2007:306:SOM:EN:HTML

Treaty of Rome, Retrieved: September 12, 2012, from http://www.eurotreaties.com/ rometreaty.pdf. 